\title{
A Baby Dumped In a Garbage Container
}

\section{Sinisa $\mathbf{F}^{*}$}

Faculty of Law, International University of Brcko District, Bosnia and Herzegovina

*Corresponding Author: Sinisa Franjic, Faculty of Law, International University of Brcko District, Bosnia and Herzegovina, Tel: +38749490460; E-mail: sinisa.franjic@gmail.com

Received date: January 30, 2018, Accepted date: February 05, 2018, Published date: February 08, 2018

Copyright: (c) 2018 Sinisa F. This is an open-access article distributed under the terms of the Creative Commons Attribution License, which permits unrestricted use, distribution, and reproduction in any medium, provided the original author and source are credited.

\begin{abstract}
This is not a fictitious title because, unfortunately, it is a real event. On the last day of 2017, citizens informed the police that Kosevo's streets in Sarajevo (the capital of Bosnia and Herzegovina) from one of garbage containers came to strange sounds like baby crying. When the cops who went out to the field opened the container, they found frostbitten and crying baby. The cops and assembled citizens were shocked because they could not believe the baby was thrown into the trash. This news was the first to publish the Sarajevo daily newspaper Dnevni Avaz (www.avaz.ba), and all media houses in the region and beyond. The baby (girl) was in a pile of rubbish, and had a skullcap on it and was wrapped in a towel. She was immediately transferred to Sarajevo's Pediatric Clinic where doctors found the baby healthy and aged between two and five days. Thanks to the timely reaction of citizens and police, the baby is saved. Why is this event important to our reader audience? It is important because it speaks, above all, of the lack of parental love for a newly born child. What can doctors and other medical professionals do in these and similar situations? They cannot do much, but what they can do of exceptionally importance for making future decisions.
\end{abstract}

Keywords: Garbage; Baby; Citizens; Police

\section{The Criminal Aspects of This Case}

The criminal law to this case is viewed as a criminal act of Murder. It is a criminal act against life resulting in the death of one or more persons. Murder is a basic criminal act of death when a person's death has been caused, and no special elements have been created that would make it a hard (qualified) or lighter (privileged) murder [1]. The action is determined as a result of death. The result of a criminal offense consists in the occurrence of a person's death, and if death did not occur, it is an attempt. The act must have a causal meaning for the occurrence of death. It is not necessary that death comes immediately. It can also occur after a long time. The answer to the above question is obtained by expertise. The cause is relatively easy to determine unless there are several conditions that compete with each other. There must be intent for the murder, direct or indirect. It must include action, causality and consequence.

Hard (qualified) murder is a murder involving qualifying circumstances such as the age of the victim (child, juvenile, adult). The age of the victim as a qualifying circumstance should be assessed according to the criteria for determining the time of committing a criminal offense. It is important to determine the time of the offense, regardless of when the incident occurred. A further qualifying circumstance is the pregnancy of a woman for which the perpetrator aware. The following is a murder that intentionally endangers the life of one or more persons, murder in a particularly cruel and treacherous way, murdering from greed, for committing or concealment of another criminal act, murdering from the ruthless revenge and murdering of the official person at a time when he/she done certain official business.

In connection with this case, it should be known how criminal law is perceived as criminal act of Infanticide. Infanticide can be committed anywhere and anytime. Most often it happens in the apartment or near the home of the woman who commits infanticide.

Birth is a big change for newborns that must adapt to life in the outside [1]. The transition from the mother's uterus to the outside world for the newborn child is a real shock. The newborn child is very sensitive and jeopardized due to its unfitness and functional immaturity of its organs. When a mother declines to provide the necessary assistance and care to a newborn child in the form of feeding, warmth etc., baby dies. Newborn babies exposed to a temperature of $15^{\circ} \mathrm{C}$ die due to the underdevelopment of thermoregulatory functions, which results in hypothermia. Death can occur very quickly, especially if the child is naked. When a child dies in such a way, during the criminal investigation and later during the criminal proceedings, the age of mother and her education should be taken into account, since it is not uncommon for the child to die because of ignorance of the mother. Always be aware of the possibility of fingering.

Primary acts of perpetration of infanticide may be the same as those occurring in the case of adult murders. However, they dictate and characterize certain specifics related to the child as a victim-the subject of the act as a completely helpless person and the situation of the committing of the criminal act. In newborns, the possibility of selfdefense is a missing. For infanticide, no need much strength, and no special means of perpetrating great offensive power.

\section{Criminal Investigation}

The investigation should do as soon as possible and to do as detailed as possible.

Reconstruction of a crime scene is essential in determining the events that took place prior to, during, and after a criminal act has occurred [2]. Physical and biological evidence will play a crucial role in linking the suspect to the victim and the location of the crime as well 
as providing support or contradictions of witness/victim/suspect recollections of the incident. An accurate and objective crime scene search yields the "story" told by the evidence so that it is reasonable and convincing to a jury. Forensic evidence is used to provide impartial facts and is often referred to as the "silent witness."

Physical evidence encompasses any and all objects that can establish that a crime has or has not been committed or can link a crime and its victim or its perpetrator [3]. But if physical evidence is to be used effectively to aid the investigator, its presence first must be recognized at the crime scene. If all the natural and commercial objects within a reasonable distance of a crime were gathered so that the scientist could uncover significant clues from them, the deluge of material would quickly immobilize the laboratory facility. Physical evidence can achieve its optimum value in criminal investigations only when its collection is performed with a selectivity governed by the collector's thorough knowledge of the crime laboratory's techniques, capabilities, and limitations.

An investigator has the responsibility of solving crimes and identifying offenders [4]. The investigative process begins with the initial investigation to determine if a crime has been committed and continues until the case has been cleared or closed. Unless an investigation is discontinued because of insufficient solvability factors or information, the investigator's responsibility continues until the court process is completed.

A criminal investigator needs to know criminal laws and criminal procedures to bring a criminal offender through the criminal justice process. An investigator should develop good prosecutor relationships by conducting investigations along legal guidelines and collecting evidence and testimony within acceptable legal guidelines. Prosecutors need admissible evidence to present their case.

\section{Biological-Medical Aspects of This Case}

The most important thing is that the baby is first examined by the pediatrician because Pediatrics is the branch of medicine that covers the childhood years. In general, the younger the child the more their physiology and metabolism differ from that of adults, but for older children these differences become less pronounced [5]. There are, however, two areas that are unique to pediatrics: physical growth and development. A good understanding of how children change in terms of growth and development in the early years is very important, and without this understanding it is not possible to practice pediatrics well. The pediatrician should determine in what condition the baby is, and may suggest additional procedures he deems necessary.

All of the available information about any incident must be carefully collected, collated and evaluated [6]. Laboratory data, both clinical and forensic, the results of radiological investigations and information from the examination of the scene where any incident took place should be carefully sought and evaluated against the clinical findings. A team approach is essential, with close collaboration of family physicians, pediatricians involved in community and hospital practice, the clinical forensic medical examiner and specialist pathologists, together with police and social welfare services. No incident should be looked at in isolation but rather in the context of the child's development and interaction with his or her family, environment and peer group. The survivors of inflicted injury or neglect in childhood must be carefully followed up, protected and their family unit supported.
Physicians usually approach clinical situations by taking a history (asking questions), performing a physical examination, obtaining selected laboratory and imaging tests, and then formulating a diagnosis [7]. The conglomeration of the history, physical examination, and laboratory tests is called the clinical database. After a diagnosis has been reached, a treatment plan is usually initiated, and the patient is followed for a clinical response. Rational understanding of disease and plans for treatment are best acquired by learning about the normal human processes on a basic science level, and likewise, being aware of how disease alters the normal physiologic processes is understood on a basic science level. In short, clinical problem solving involves three basic steps: (1) making a diagnosis, (2) initiating a therapy, and (3) monitoring the patient's response. In accordance with their expert knowledge and medical profession, it is of utmost importance that the pathologist performs a review and determines in what state are the internal organs. The baby is thrown into the garbage container and does not know how long it was there. Therefore, it is necessary to determine the state of the organs because there is a possibility that some are damaged.

DNA analysis needs to be done because it is possible to detect the details of the human body and thus prove a number of important facts.

DNA is the genetic blueprint of an individual [8]. It is present in every cell of a person's body, not only in the cell's nucleus but also in its cytoplasm, in special energy-producing structures called mitochondria. Of great importance is the fact that, except for the rare occurrence of a mutation, the DNA in every cell of the person's body is identical. As a result, DNA can be taken from saliva, blood, skin cells, sweat, bone cells, or hair for individual identification. Body fluids containing cells are often collected as biological evidence. In the case of saliva, the cells are derived from the inner lining of the person's cheek; in sweat, the cells come from the tissue surrounding the sweat glands and pores. In addition to these sources of DNA, one must add semen in the case of a male and breast milk in the case of a female individual.

Regardless of the situation, the DNA molecules from a crime scene come from a less than pristine environment that is normally found in molecular biology laboratories [9]. Just as important is the fact that the retrieved biological sample may be limited in quantity. Thus, accurate sample analysis is critical since a forensic scientist may only obtain enough evidence for one attempt at analysis.

DNA testing is an extremely powerful tool that has been used successfully to investigate many areas of scientific research, and to solve problems in biology [10]. If the tests are performed correctly, the results of DNA testing almost always point scientists in the right direction, even when the DNA test results contradict a mother's biological connection to her child, as in the case of the chimera woman called Jane in Boston.

When this or similar event occurs, there is a suspicion that mother and father and other family members are mentally ill because no one normal could do something like that. For this reason, a psychiatrist who should perform psychiatric examinations has a very responsible task. At first sight it may be thought that mental illness should be treated like any other form of medical disorder [11]. However, there are special difficulties involved in deciding precisely what we mean when we say that someone is mentally ill. Perhaps this is inevitable, given the nebulous nature of mental illness and its overlap with antisocial behavior, the holding of bizarre beliefs, and eccentric lifestyles. In addition, the mentally ill are often stigmatized and misunderstood. 
Lawyers and psychiatrists and other health workers need to understand each other's viewpoint and to use the same language in referring to psychological and psychiatric conditions [12]. While everyone except the psychiatrist tends to have his own idea of what is meant by, say, schizophrenia or depression, in legal matters the diagnosis must be accurate and precise and generally accepted.

This is achieved through the use of classificatory systems which lay out categories of mental disorder, and the criteria for specific diagnoses, with clinical descriptions of these, including their natural history. The history can give valuable insights, in some cases, on the person's mental state before any incident and a forecast of the probable outcome. The first may be relevant in matters of competence to make reasonable decisions, criminal responsibility and impairment of function. The second, concerning prognosis, is of particular interest where compensation is involved. It is important to remember, however, that the diagnosis of a particular mental disorder does not necessarily carry any implications as to its cause.

The most common cause of such behavior is post-natal depression. Women are seen as the victims of their bodies, particularly the raging hormones that plague their lives from adolescence to late middle age [13]. Science, clinical experts and popular myths portray women as emotionally and intellectually unreliable, unpredictable, deficient and a psychological puzzle-all because, for some of their adulthood, they have the capacity to ovulate. Post-natal depression is part of that belief system. For centuries women have been dying from childbirth and experiencing severe ill-health caused by the stresses and strains of motherhood. So why is depression in the weeks and months following birth perceived as 'atypical'? Women's capacity and determination to bear and nurture children under adversity seems endless; but it is not their resilience that interests scientists and clinicians. It is their failure.

Disease, in its broadest sense, is any compromise to the normal function of the body and the systems of which it is composed [14]. However, it is best to consider health and illness as two extremes of a continuum. At one extreme is severe, disabling, or life-threatening illness with corresponding effects on our physical and emotional wellbeing. At the other extreme is ideal, perfectly good health, a state of physical and mental well-being wished for but rarely attained. Between these two extremes are many gradations of health and disease, ranging from mild or short-term illness that limits activities to some extent to moderate good health that falls short of the ideal state.

\section{Conclusion}

A case like this is inducing disgusting in the public. There is no doubt that this is a criminal act that needs to be strictly sanctioned.

Medical professionals cannot do much to do, but the minimum they can do is described in this case study. It should be particularly emphasized is the humanity of medical professionals because they saved the baby from almost certain death. The question is what would happen to the baby that citizens did not notice strange sounds from the garbage container at a time. Along with medical professionals, as major humanists, they proved not only the citizens who informed the police about the weird sounds which coming from the garbage container, but also the two policemen who came out on the ground after the citizens' notification.

What to say about the humanity of the mother's baby? Father? Family? How could they have done so? Are all of them sick? These are just some of the questions that will be answered by medical professionals in the coming court proceedings.

The further fate of the baby will depend of the state of Bosnia and Herzegovina. After the criminal procedure has been carried out, the court will decide of the depriving of the baby from the mother/father/ family and the baby will be sent to the competent social work center. The Center for Social Work will most likely place a baby in a Home for uninhabited and abused children.

\section{References}

1. Pavisic B, Modly D, Veic P (2012) Criminalistics-Book 2, Dusevic and Krsovnik Press, Croatia.

2. Fish JT, Miller LS, Braswell MC, Wallace J, Edward W (2014) Crime scene investigation (3rd edn), Elsevier and Oxford Press, UK.

3. Saferstein R (2015) Criminalistics-An introduction to forensic science (11th edn), Pearson Education Limited, UK.

4. Palmiotto MJ (2013) Criminal investigation (4th edn), CRC Press, Taylor \& Francis Group, US.

5. Rudolf M, Levene M (2006) Paediatrics and child health (2nd edn), Blackwell Publishing, US.

6. Busuttil A, Keeling JW (2008) Paediatric forensic medicine and pathology, CRC Press, Taylor \& Francis Group, US.

7. Toy EC, Uthman MO, Uthman Ed, Brown EJ (2008) Case files-pathology (2nd edn), The McGraw-Hill Companies, USA.

8. Kobilinsky L, Levine L, Margolis-Nunno H (2007) Forensic DNA analysis, Chelsea House Publishers, USA.

9. Butler JM (2005) Forensic DNA typing: biology, technology and genetics of STR markers (2nd edn), Elsevier Publishing, UK.

10. Fitzgerald-Hayes M, Reichsman F (2010) DNA and biotechnology (3rd edn), Elsevier Publishing, UK.

11. Stauch M, Wheat K, Tingle J (2002) Sourcebook on medical law (2nd edn), Cavendish Publishing Limited, UK.

12. Gomez J (1997) Psychiatry, Cavendish Publishing Limited, UK.

13. Nicholson P (1998) Post-natal depression-psychology, science and the transition to motherhood, Chelsea House Publishers, USA.

14. Reisner EG, Reisner HM (2017) Crowley's an introduction to human disease-pathology and pathophysiology correlations (10th edn), Jones \& Bartlett Learning Publishing, US. 